revista ANTHROPOLÓGICAS

Ano 24, 31(2): 86-121, 2020

\title{
(Toxi)Cidade do Aço: Infraestrutura siderúrgica e contestação social em um caso de contaminação por resíduos industriais
}

Maria Raquel Passos Lima ${ }^{a}$

$\mathrm{O}$ artigo analisa o caso de contaminação do 'condomínio Volta Grande IV' por resíduos industriais da Companhia Siderúrgica Nacional (CSN), em Volta Redonda no Sul Fluminense (RJ). A noção de 'infraestrutura siderúrgica' é desenvolvida como chave de análise capaz de restituir conceitual e etnograficamente a dimensão invisível da produção siderúrgica, ao enfocar o lado residual da infraestrutura, caracterizado pela toxicidade. O objetivo do artigo é compreender as relações de poder e dinâmicas políticas engendradas pelas substâncias tóxicas na configuração de arenas de disputa em torno de seus potenciais usos e efeitos. A partir da apresentação de quatro cenários a contaminação, a controvérsia científica, o processo judicial e a arena ambiental a narrativa etnográfica adota o tempo como objeto privilegiado, discutindo as formas como temporalidades divergentes atravessam diferencialmente a infraestrutura e seus efeitos políticos na construção de estratégias corporativas e processos de contestação social, que terminam por conformar uma 'política resiliente'.

Justiça ambiental, Resíduos tóxicos, Siderurgia, Infraestrutura, Tempo.

Neste artigo $^{1}$ proponho a noção de 'infraestrutura siderúrgica' como estratégia interpretativa para pensar, à luz etnográfica, o caso de contaminação do bairro conhecido como condomínio Volta Grande IV, por resíduos industriais da Companhia Siderúrgica Nacional

a Professora Adjunta, Departamento de Antropologia do Instituto de Ciências Sociais (ICS/ UERJ). Email: mariaraquel.passoslima@gmail.com. 
(CSN), em Volta Redonda, município do Sul Fluminense (RJ), e as disputas políticas que o envolvem. A pesquisa teve sua fase de trabalho de campo realizada ao longo do ano de 2017 e sua metodologia consistiu em acompanhar um conjunto de reuniões e eventos públicos relativos ao caso, assim como desenvolver entrevistas qualitativas em profundidade com atores relevantes, além do acompanhamento do caso na imprensa e da análise de documentos que compõem o processo judicial.

Em sua estrutura textual, a discussão é precedida por uma introdução teórico-metodológica que justifica a abordagem infraestrutural do caso, por sua plasticidade conceitual, por seu caráter relacional e por inscrever a discussão antropológica pela chave da materialidade e da (in)visibilidade, permitindo à análise etnográfica incorporar sob sua alçada os elementos marginais, situados fora do campo de visão, ou dentro dele, embora de modo opaco. A análise procede a um jogo de reversão figura-fundo entre regimes de visibilidade próprios aos resíduos tóxicos e sua dinâmica temporal, e é composta pela descrição de quatro cenários, que expõem distintos níveis e dimensões que constituem a infraestrutura siderúrgica. Em um momento inicial, a discussão apresenta os elementos que compõem sua parte mais visível, a partir de uma breve narrativa histórica que contextualiza e qualifica múltiplos aspectos e escalas da relação entre empresa e espaço urbano, apontando para especificidades da cidade de Volta Redonda. Em seguida, no primeiro cenário, apresento o caso de contaminação do Volta Grande IV como uma dimensão invisível ou residual da infraestrutura siderúrgica, situando analiticamente a contaminação como uma parte inerte que ao ser tematizada possibilita explicitar relações e agenciamentos latentes, vigentes nas sombras. Conexões entre a estrutura produtiva da CSN e os espaços urbanos são rastreadas a partir das qualidades das substâncias tóxicas e de um conjunto de dispositivos tecnopolíticos que operam a sua complexa gestão.

Com esse movimento, a abrangência da infraestrutura se amplia e a análise é desdobrada para três outros cenários, uma controvérsia 
científica com a realização de uma pesquisa no bairro, um processo judicial envolvendo a contaminação do local, e a mobilização da sociedade civil na arena ambiental, a partir dos quais é possível compreender como as relações de poder atravessam a infraestrutura e os modos nos quais a contaminação e seus efeitos são agenciados pelos atores situados diferentemente numa arena de disputa em torno da segurança/risco e potenciais danos à população local em termos de saúde ambiental. Dentro desse contexto, que aponta profundas assimetrias nas relações de poder entre os diversos agentes envolvidos, o trabalho adota o tempo como foco da análise e objeto privilegiado para a compreensão da política em torno da toxicidade da infraestrutura siderúrgica, discutindo apropriações e efeitos de temporalidades divergentes nas estratégias corporativas e nos processos de contestação social no universo investigado, que terminam por configurar uma 'política resiliente'.

\section{Abordagem infraestrutural: plasticidades e (in)visibilidades conceituais e etnográficas}

Desde que a noção de infraestrutura adentrou a discussão antropológica, passando a ser progressivamente submetida à perspectiva etnográfica (Star 1999), muitos debates se abriram num processo continuamente renovado (Anand et al 2018; Grahan \& Mcfarlane 2015; Hetherington 2019; Larkin 2013; Murphy 2013; Venkatesan et al 2018), que evidencia a diversidade e plasticidade de maneiras de conceber e analisar infraestruturas, e seu rendimento para a compreensão de complexos fenômenos da vida urbana na contemporaneidade.

De tal plasticidade decorre não apenas a riqueza como também a dificuldade que a noção apresenta, expressa por um indisciplinamento conceitual que advém das características de sua ontologia própria, já que infraestruturas contém a dualidade de serem não apenas coisas, mas "relações entre coisas" (Larkin 2013:329). Essa qualidade relacional (Star 1999; Larkin 2013) inerente às infraestruturas é o que remete diretamente à dimensão metodológica que a constitui. Pois 
se infraestruturas não são coisas que estão simplesmente 'lá', dadas por princípio, mas redes relacionais e heterogêneas em proliferação, atravessadas por diversas escalas e sendo operadas por diferentes níveis simultaneamente, a questão de sua composição, suas fronteiras e limites torna-se incontornável.

Ao afirmar que a discussão sobre uma infraestrutura é sempre um ato categorial, Larkin (2013) traz o debate para a chave teórico-metodológica, ressaltando sua definição como um trabalho que pressupõe uma análise cultural, compromissos epistemológicos e políticos, e que, portanto, depende de escolhas, de um foco e de recortes. Enquanto uma "tática interpretativa" (Hetherington 2019:6), quaisquer escolhas precisarão selecionar quais aspectos e níveis da composição heterogênea das infraestruturas abordar, tendo clareza das partes que serão ignoradas, na medida em que a adoção do que se vê como infraestrutural irá inevitavelmente deixar outras possibilidades de relações de fora.

A dimensão (in)visível da infraestrutura e sua inscrição em regimes de visibilidade específicos é um ponto sensível da discussão. A ênfase excessiva na condição invisível das infraestruturas dada num primeiro momento (Star 1999; Graham \& Marvin 2001) foi criticada e problematizada, levando à formulação de que não se trata de afirmar invisibilidade ou a visibilidade como uma condição inerente, mas de entender a invisibilidade como um aspecto que repousa na extremidade de uma gama de visibilidades que se deslocam num espectro, no qual o que interessa é "examinar como a (in)visibilidade é mobilizada e por quê" (Larkin 2013:336). Desse modo, as infraestruturas sempre possuem uma dimensão exposta e visível, deixando outras na sombra, que, sem nitidez, deixam de ser objeto de apreciação, o que opera sua exclusão do campo das disputas políticas, mobilizando, ao mesmo tempo, o poder sub-repticiamente.

A dimensão material, espacial e tecnológica das infraestruturas, e sua relação com o meio urbano, em regra constitui sua parte mais espetacular e visível e forma a base para a gestão da vida nas cidades 
em sua dimensão mais concreta. No entanto, muitos aspectos menos evidentes como a poética, os papéis, a burocracia, se mostram relevantes para o entendimento das dinâmicas que agenciam e atravessam as infraestruturas, especialmente para a compreensão de suas dimensões políticas e ambientais, na medida em que as infraestruturas alteram radicalmente paisagens e reconstroem materialmente o ambiente, ao mesmo tempo em que diferenciam populações e sujeitos através de subordinação, colonização, racialização e uma série de violências (Anand 2018:5).

\section{A 'cidade do aço': o espaço urbano como infraestrutura siderúrgica}

A criação da Companhia Siderúrgica Nacional (CSN) na década de 40 do século XX se encontra na origem do município de Volta Redonda, que se constituiu no entorno e em função da siderúrgica, sendo por isso conhecido popularmente como 'cidade do aço’. A construção da companhia, nesse contexto, se inscrevia como parte do plano nacional-desenvolvimentista forjado no período do Estado Novo, sendo um elemento central da estratégia de desenvolvimento da indústria nacional. A instalação da Companhia trouxe significativas consequências para o desenvolvimento de toda a região do Sul Fluminense (Ramalho \& Fortes 2012), tornando Volta Redonda uma das cidades industriais mais emblemáticas do país, na medida em que o empreendimento se revestiu de forte carga simbólica.

A história de Volta Redonda, e seu desenvolvimento, foi marcada pelos ciclos de expansão promovidos pela CSN desde a sua criação (Lima 2013). O caráter de 'cidade-empresa' (Piquet 2012) trouxe implicações para as formas nas quais o município se desenvolveu, condicionado a se conformar às necessidades da Companhia. A relação de poder da empresa com a cidade se expressava também através da conformação do espaço urbano. Este era estruturado por laços verticais (Ramalho et al 2013:180), que "confun- 
dia laços industriais com a dominação sobre o trabalhador e suas esferas de reprodução" (Lima 2012:205). Tal controle se espraiava para o território da cidade, com o princípio disciplinador aplicado aos locais de moradia e tipos de habitação, separando categorias de trabalhadores e classes sociais a partir da disposição das casas no espaço urbano (Lima 2012).

Esta ascendência sobre os trabalhadores, constituída por uma dimensão tutelar, também se expressava através da concessão de benefícios sociais, fazendo com que a CSN, na prática, operasse uma intervenção em todos os níveis na vida dos operários, que iam desde a formação técnica, até os espaços de lazer, passando pelos serviços básicos (Veiga \& Fonseca 1990; Lima 2010:38)

Esta configuração sociopolítica aponta para uma relação histórica de controle e dependência operada pela Companhia sobre a população e os demais agentes locais, incluindo o poder público e suas possibilidades e esferas de ação, com a empresa exercendo influência sobre os governos municipais através da indicação de antigos quadros de funcionários para a prefeitura (Lima 2012:206).

A partir dos anos 1980, diante de uma conjuntura de fortalecimento de organizações da sociedade civil e movimentos sociais, é possivel sentir uma inflexão na hegemonia operada pela empresa na cidade. Merecem destaque o sindicato dos metalúrgicos e, sobretudo, o trabalho da ação pastoral da igreja católica da localidade, que carrega um histórico de apoio às causas populares e dos trabalhadores em Volta Redonda, sob o comando do bispo Dom Waldyr Calheiros (Costa et al 2001). O aparecimento de um movimento sindical-popular mais articulado constituiu um tecido associativo "capaz de questionar a influência da CSN sobre o desenvolvimento da cidade" (Lima 2012:206).

Durante a década de 1990, a Companhia passa por um controverso processo de privatização, que correspondeu à adoção de novas estratégias corporativas e à operacionalização de uma lógica produtiva distinta, assim como impôs novos contornos ao desenvolvimento local, 
com impactos econômicos e políticos significativos. Caracterizada até então pela atuação nacional, com a privatização, a Companhia passa a atuar em uma rede de produção internacional, mantendo, no entanto, sua principal unidade, a Usina Presidente Vargas (UPV), inaugurada em Volta Redonda em 1946 com o portfólio "mais completo e diversificado de aços planos da América Latina” (Ramalho et al 2013:179).

Os efeitos do processo de privatização foram agudos para o município, se revertendo na perda de milhares de postos de trabalho, terceirizações e desemprego acentuado que levou a uma crise social. Ao mesmo tempo em que este processo operou um distanciamento da empresa em relação à cidade (Ramalho 2012:237; Ramalho et al 2013:180), a relação de dominação e controle exercida historicamente pela Companhia se manteve mesmo após as mudanças organizacionais com sua transformação em um conglomerado empresarial, (Lima 2013), inserido em redes globais de produção (Santos 2015).

Em contrapartida, o cenário pós-privatização em Volta Redonda foi marcado por um conjunto de mobilizações nas quais agentes locais diversos se articularam em iniciativas inéditas na região com o objetivo de reverter os efeitos socialmente prejudiciais provocados pelas mudanças nas estratégias empresariais da CSN (Lima 2012; Ramalho 2012; Ramalho et al 2013). Nos anos 2000, o afastamento entre a CSN e a cidade se acentuou com o anuncio de um conjunto de novas demissões na unidade de Volta Redonda (Lima 2012; 2019). Esse movimento leva a uma nova mobilização, denominada Fórum Demissão Zero (Lima 2010), cuja articulação e discussões desembocam na criação, em 2009, da Comissão Ambiental Sul.

Como instância da sociedade civil, a Comissão busca discutir e propor estratégias de atuação constituindo um "campo de lutas sociais e de ação coletiva de resistência às políticas e atitudes da empresa" (Ramalho et al 2013:183) no que tange ao resguardo dos direitos humanos e do meio ambiente. A temática ambiental retoma assim, de outro viés, o relacionamento da CSN com a localidade, expondo os problemas dessa relação. 


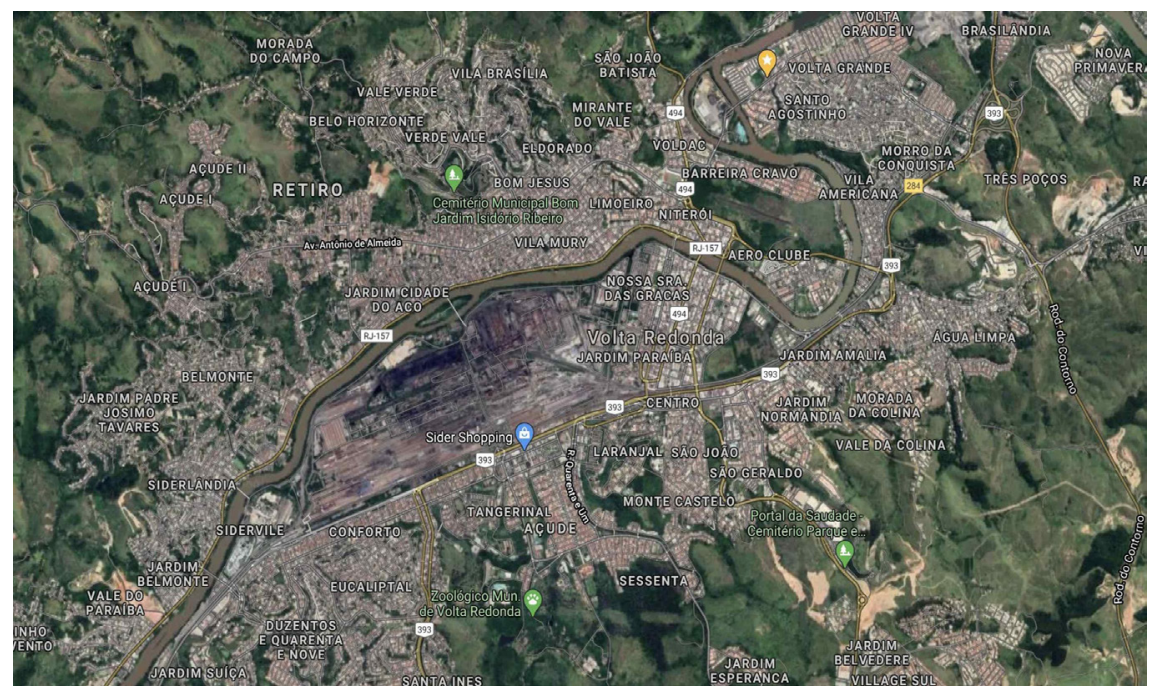

Fotografia 1: Imagem de satélite da Companhia Siderúrgica Nacional no centro do espaço urbano da cidade de Volta Redonda.

A atividade mínero-siderúrgica requer a exploração intensa de recursos naturais em seus processos produtivos e extrativos, além de ser geradora de inúmeros poluentes (Milanez \& Porto 2008:11), o que torna esses setores e corporações particularmente sujeitos à contestação social. A descrição do caso de contaminação do Volta Grande IV irá operar uma 'inversão infraestrutural' Bowker (1994), trazendo para o centro da discussão o lado residual e as relações menos visíveis da infraestrutura siderúrgica para analisar as relações de poder que a atravessam.

\section{A latência da contaminação: toxicidades do aço}

O condomínio ou conjunto habitacional Volta Grande IV se localiza no bairro Santo Agostinho, na zona leste do município de Volta Redonda e a relação com a CSN atravessa sua história desde sua origem $^{2}$. No início dos anos 1990, a Companhia doou ao Sindicato dos Metalúrgicos do Sul Fluminense um terreno para a construção de 
residências para os funcionários da empresa. Em 1998, o condomínio, que hoje possui cerca de 827 imóveis, foi construído pela Caixa Econômica Federal.

No período entre 1986 e 1999, a CSN utilizou uma área do bairro como depósito de resíduos industriais provenientes da produção de aço da Usina Presidente Vargas. Esta área foi dividida em duas células para armazenamento de resíduos, localizadas no interior de uma empresa situada ao lado do terreno onde foi construído o condomínio. A empresa Harsco presta serviço para a CSN, e é responsável pela operação dos seus resíduos siderúrgicos, fazendo estocagem e beneficiamento de escória de aciaria, utilizada na construção civil e de estradas.

A CSN operou o aterro de resíduos perigosos na área sem executar nenhuma exigência relativa ao controle das operações, como que tipo de resíduos eram depositados e como monitorá-los. Sem monitoramento, ocorreu um vazamento dos resíduos industriais em função de uma falha na tubulação dos poços percolados, construídos para monitorar e drenar as células.

Um dos poços estava embaixo de 4 casas do condomínio. Elas foram desapropriadas pela CSN e demolidas. No local, foi construída uma quadra poliesportiva. Em 2003, começam a aparecer rachaduras e líquidos com cheiro forte no chão das casas e moradores ficam preocupados em relação ao potencial risco oferecido. Uma comissão de moradores do condomínio, que havia sido criada para reivindicar visto de construção e saldo devedor das casas, passa então a acompanhar e atuar no desenrolar do caso.

Considerando a contaminação do condomínio Volta Grande IV como possivelmente o "maior desastre ambiental da história recente de Volta Redonda" (Ramalho et al 2013:183), partimos da contaminação e dos resíduos como chave de análise teórico-metodológica para qualificar e desenvolver a noção de infraestrutura siderúrgica. Resíduos, poluição e toxicidade não são "externalidades" (Liboiron et al 2018:334), "efeitos colaterais" (De Angelis 2004:77) ou "subprodutos não intencionais" (Ofrias 2017:16) dos sistemas produtivos, mas 
uma dimensão constitutiva do capitalismo industrial e da organização empresarial em redes globais de produção e de destruição (Liboiron et al 2018; Ofrias 2017; De Angelis 2004; Dicken 2011; Gille 2010; Mcgrath-Champ et al 2015; Herod et al 2014), que produzem desigualdades e zonas de sacrifício (Lerner 2010), afetando diferentemente corpos, comunidades e territórios.

A toxicidade constitui estruturas de poder, produzindo "oportunidades invisíveis para a acumulação de capital” (Ofrias 2017:16), a partir não de um efeito involuntário, mas de uma "imposição consciente de poder sobre um grupo particular de pessoas" (Ofrias 2017:2; De Angelis 2004).

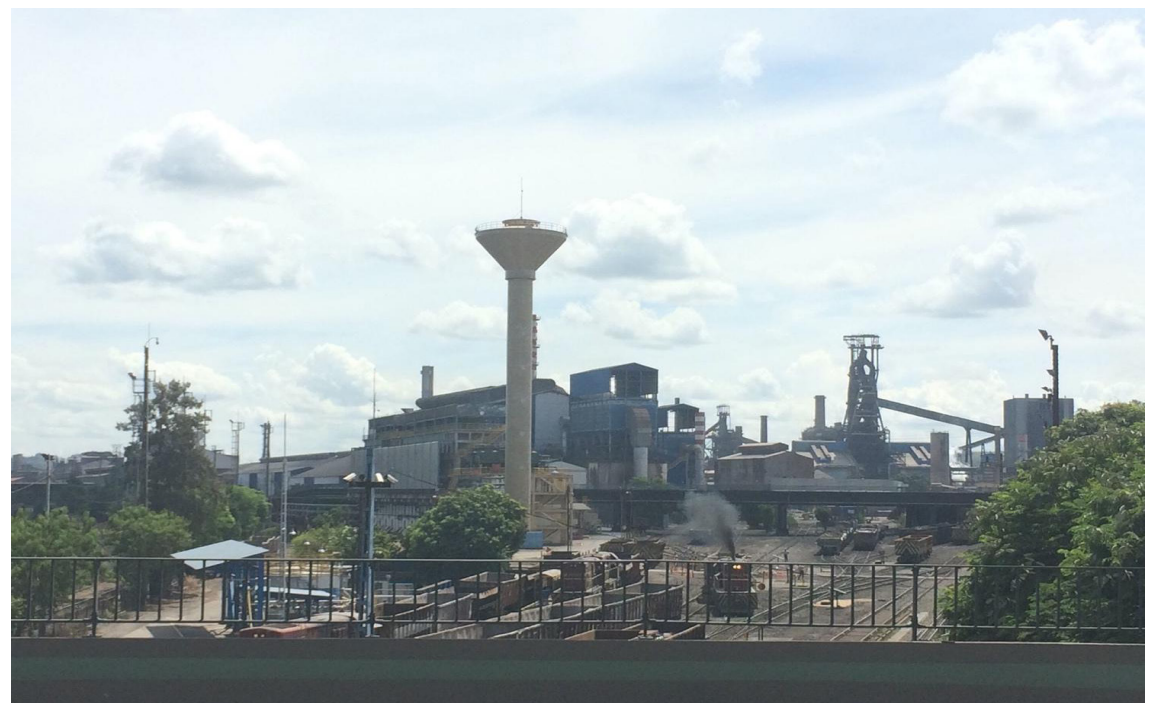

Fotografia 2: Instalações da Usina Presidente Vargas - CSN.

Pensar os resíduos industriais como parte da infraestrutura siderúrgica se mostra, portanto, uma estratégia para recuperar analiticamente os vínculos entre empresa e território que operam no polo opaco do regime de visibilidade, e as relações de poder e disputas po- 
líticas que engendram. Começamos por restituir o que está à margem como parte de uma totalidade mais ampla, incorporando analiticamente à estrutura produtiva da empresa diversos espaços da cidade e um conjunto de aparatos e elementos que operam a sua gestão. Para isso, retraçamos o aparato de gestão dos resíduos industriais e sua disposição no espaço urbano, que além da estrutura industrial da Usina Presidente Vargas, de toda a estrutura logística e de transporte ferroviário, conta também com a manutenção, operada em caráter ilegal (MPF 2012:13), de diversos aterros de resíduos industriais espalhados pela cidade, como Márcia I, Márcia II, Márcia III, Márcia IV, Wandir I e Wandir II (Panco), e ainda com o aterro no bairro VGIV, já que muitos terrenos no município são propriedade da CSN.

No entanto, para além da estrutura física que compõe o aparato material da gestão e disposição de resíduos, é preciso considerar também a materialidade das próprias substâncias dos resíduos industriais e suas qualidades. Investigando a vida das substâncias tóxicas e seus agenciamentos, tornamos visível e conceitualmente rentável o lado residual, inerte e latente da infraestrutura siderúrgica. Desvela-se, assim, a sua dimensão tóxica, a toxicidade do aço.

Nesse sentido, é na relação com o tempo que a caracterização da infraestrutura siderúrgica pode incorporar a contaminação, os resíduos e a toxicidade, na medida em que eles dependem de temporalidades específicas para que o efeito da agência de sua materialidade no mundo adentre o campo do sensível e, ganhando visibilidade, também a arena política. Para enquadrar o alcance, a escala e os efeitos da toxicidade da infraestrutura siderúrgica, me baseio na noção de 'infraestruturas químicas' de Murphy, que as definem como

"as distribuições espaciais e temporais de substâncias químicas produzidas industrialmente tal como elas são produzidas, consumidas e se tornam móveis na atmosfera, se estabelecem em paisagens, viajam nos cursos d'água, lixiviam de mercadorias, são reguladas (ou não) pelos Estados, monitoradas por especialistas, projetados por indústrias, absorvidos por corpos, metabolizados fisiologicamente, bio-acumulam em mudanças alimentares, desintegram com o tempo 
ou persistem. Infraestruturas químicas são reguladas e ignoradas, estudadas e ainda cobertas de incertezas" (Murphy 2013:105).

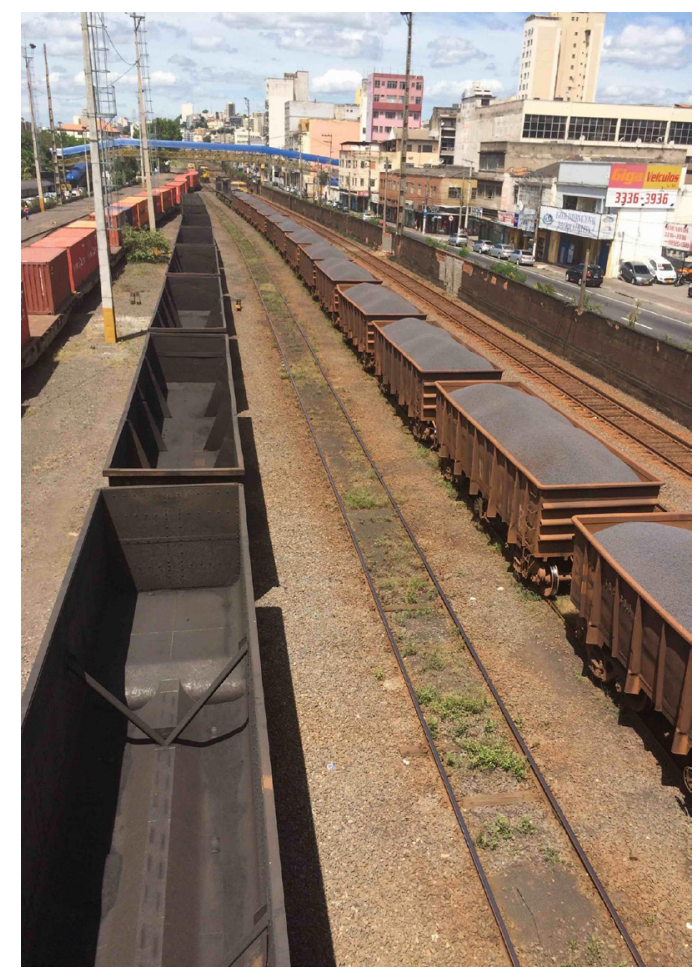

Fotografia 3: Sistema de transporte ferroviário de fornecimento e escoamento da produção siderúrgica.

Compreender a contaminação e os resíduos como parte da infraestrutura siderúrgica é investigar a relação entre o tempo e os tóxicos, como o tempo, em especial a vagarosidade, persistência, acumulação crescente e latência, incide de modo produtivo nos regimes de visibilidade e nas configurações das relações de poder, na medida em que a infraestrutura, e sua toxicidade, vai moldando desigualmente e materialmente a vida humana e não humana no tempo e no espaço. 


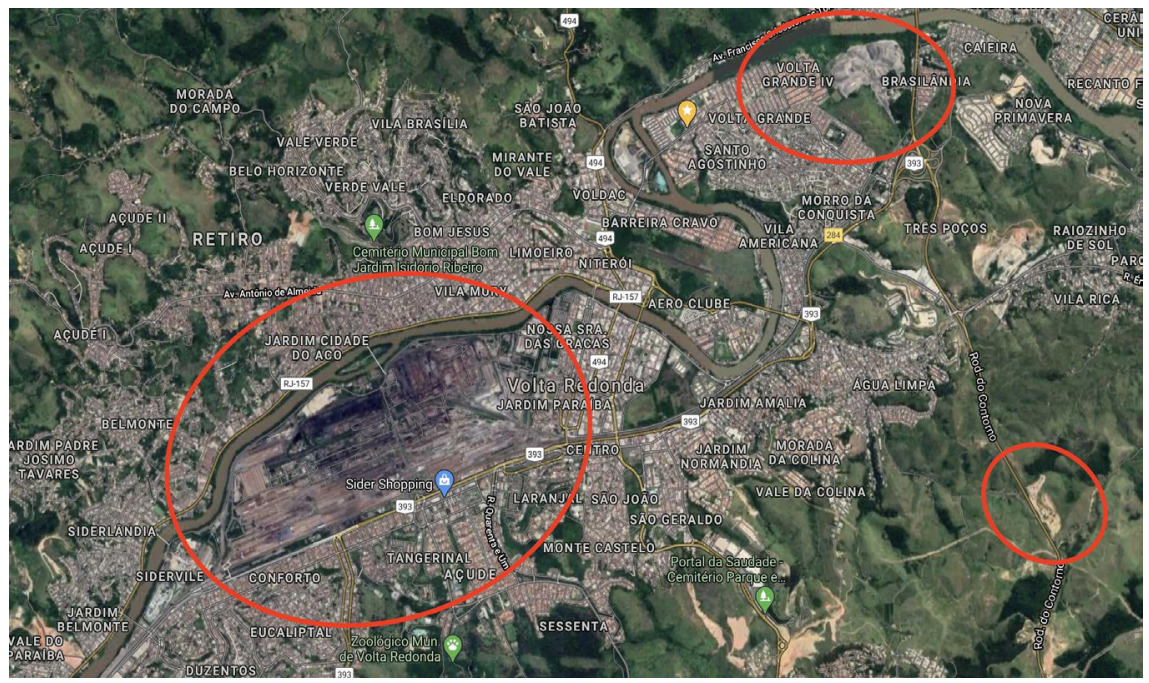

Fotografia 4: Instalação da Usina Presidente Vargas e dois aterros de resíduos da CSN na cidade, um deles no bairro do Volta Grande IV, que compõem a Infraestrutura Siderúrgica.

A centralidade dos resíduos e da contaminação tóxica para a reprodução dos sistemas produtivos do industrialismo e do capitalismo global leva à formação de 'paisagens tóxicas' que exigiriam a investigação do seu acúmulo tóxico nos corpos e no ambiente. Stewart (2017) advoga por uma arqueologia da toxicidade para analisar a persistência das substâncias no tempo, captando sua longa duração, dado que ela projeta o futuro de forma não determinística. As vidas biológicas dos intoxicantes variam amplamente, enquanto alguns duram por horas, outros podem durar décadas, assim como seu agenciamento com os corpos e organismos, que podem matar rápido ou acumular no corpo através de uma exposição de longo termo.

A especificidade da temporalidade da contaminação tóxica, o andamento lento de seu ritmo existencial e da atualização de seus efeitos nocivos, levou ao conceito de 'violência lenta' por Rob Nixon (2011). Por ocorrer 'gradualmente e fora da vista', é uma violência 'de destrui- 
ção atrasada, dispersa no tempo e no espaço', que normalmente não é vista como violência, porque não é instantânea, nem espetacular. Seus efeitos deletérios ocorrem em várias escalas temporais e sua relativa invisibilidade colocam desafios representacionais, narrativos e estratégicos (2011:2).

A produção de resíduos e a condição tóxica inerente ao desenvolvimento industrial vêm acompanhadas, portanto, da fabricação e proliferação de riscos que ameaçam a saúde das populações e do ambiente, gerando situações de profunda incerteza sobre a segurança da vida cotidiana. Como disse o representante da comissão de moradores do condomínio Volta Grande IV: "Nós precisamos ter a certeza que nossos filhos vão poder viver naquela comunidade sem ficar doente. [...] Porque, independente do solo estar contaminado ou não, nós somos bombardeados o tempo todo com a dúvida. A dúvida é o nosso maior problema." (Evento público - I Forum Ambiental de VR 22/02/2017).

Diante da incerteza gerada pela presença dos tóxicos e da indefinição em torno dos riscos e dos danos causados pela contaminação química, as questões relacionadas a problemas sanitários, ambientais e de saúde transformam-se em controvérsias públicas. A condição invisível, latente e insidiosa dos intoxicantes torna a ciência a mediação necessária capaz de conferir visibilidade e de dar inteligibilidade a essas substâncias, permitindo avaliar os perigos e as medidas, preventivas ou paliativas, necessárias diante das situações de contaminação. $\mathrm{O}$ conhecimento é essencial na identificação e caracterização de substâncias tóxicas, bem como na legitimação pública de diferentes políticas (Boudia \& Jas 2014:2).

No entanto, a ciência, enquanto um processo social, também é atravessada por relações de poder, sujeita a controvérsias e a usos políticos. Ao iniciar a pesquisa sobre a contaminação no Volta Grande IV, o caso havia se tornado uma controvérsia pública na qual o conhecimento científico adentrava a arena política, a partir de 'disputas definicionais' (Beck 2010) em torno da extensão, do grau e da urgência 
dos riscos e do reconhecimento e possíveis formas de ação em torno da toxicidade. A ciência e a regulamentação são "pontos de passagem obrigatórios", pois "definem a toxicidade nos discursos dominantes" e, portanto, "devem ser considerados ao evocar ou desafiar as noções dominantes de toxicidade" (Liboiron et al 2018:336). No entanto, como mostrou Auyero \& Swistun (2008), a incerteza tóxica é um processo social também construído pelas ações da mídia, das empresas, dos agentes públicos.

\section{O prolongar da ciência: a controvérsia sobre a segurança do bairro}

Em fevereiro de 2017, eu participava de uma reunião da Comissão Ambiental Sul, quando um dos presentes relatou sua estranheza ao ver uma propaganda da CSN aparecer nos meios de comunicação da cidade, intitulada Volta Grande IV, bairro seguro. Nela a empresa convidava para uma reunião de apresentação dos resultados dos estudos ambientais no condomínio. O grupo reunido discutiu hipóteses sobre os sentidos da propaganda e possíveis ações diante dela, uma das decisões foi a elaboração de um ofício a ser enviado ao procurador do Ministério Público Federal.

Um dia depois, circula a notícia de que a Justiça Federal havia acolhido o pedido do MPF para suspender a reunião, que seria promovida pela Companhia Siderúrgica Nacional (CSN), de forma unilateral, no bairro Volta Grande IV no dia seguinte. Os principais argumentos levantados foram que 1) a reunião confundiria a população, já que havia um estudo ainda em andamento a respeito da contaminação do bairro realizado pela Fiocruz ${ }^{3}$; 2) o evento foi marcado sem a consulta dos envolvidos; 3) a difusão da imagem de bairro seguro veiculada pela propaganda era irresponsável diante do histórico de contaminação local.

Com a suspensão, o MPF decide realizar uma reunião no bairro, promovendo uma conversa entre todos os atores sociais, inclusive com a empresa, para proporcionar os esclarecimentos técnicos neces- 
sários do caso, e mostrar os trabalhos que estão sendo desenvolvidos pela Fiocruz, em convênio com a Prefeitura de Volta Redonda, a fim de avaliar os impactos à saúde da população. $\mathrm{Na}$ audiência pública, o procurador afirmou "a única certeza que a gente tem é a incerteza”. O representante do Instituto Estadual do Ambiente (INEA) disse categoricamente que não concordava com a segurança ambiental do bairro. Afirmou que diversos estudos não apresentados ainda teriam que ser realizados, e que não corroborava com a posição da CSN. Os pesquisadores da Fiocruz apresentaram a proposta da pesquisa que estava em sua fase inicial, ressaltando a complexidade do processo e que o interesse era avaliar a saúde da população diante da exposição aos contaminantes.

Dias depois, a CSN finalmente apresentava os resultados do seu estudo sobre o bairro VGIV para a população local, feito pela empresa norte americana NewFields. Chamou a atenção na apresentação o tempo gasto ressaltando as qualidades e excelência da empresa, de seus laboratórios e clientes, que ocuparam mais da metade da exposição. Repetindo reiteradamente seu caráter "independente”, os representantes da empresa de consultoria concluíram que os resultados de nenhuma das amostras apontaram compostos químicos em quantidade e em locais que pudessem causar danos à saúde dos moradores, e que a contaminação no bairro não oferecia riscos.

Para os objetivos desse texto, vale ressaltar as radicalmente opostas compreensões a respeito das substâncias tóxicas e seus riscos apresentadas pelos representantes das duas instituições. Os estudos da NewFields forjavam certezas que resultavam na prática em um processo de produção social da incerteza tóxica (Auyero \& Swistun 2008), fornecendo, em vista de objetivos específicos, informações que seriam contestadas por outros atores, contribuindo para uma situação de insegurança. Se os resultados divulgados conseguiram tranquilizar parte dos moradores que assistiu à reunião, o efeito no grupo de moradores mais mobilizados que compunham a comissão do VGIV foi o aprofundamento das desconfianças e incertezas. 
Como compensação, esses moradores, integrantes da comissão, se tranquilizavam em vista da garantia de que a pesquisa da Fiocruz seria realizada, que viam como uma vitória deles, e demonstravam entusiasmo com a perspectiva de obterem um laudo confiável, fruto de um processo que reconheciam como legítimo. "Isso aqui é uma luta nossa. O que a gente queria era trazer um órgão de respeito para investigar isso aqui para a gente. Hoje, a gente conseguiu. Graças a Deus" (Entrevista concedida em 25/01/2107).

Por um conjunto de fatores próprios às exigências e condições de possibilidade para o desenvolvimento de qualquer pesquisa científica, mas, em especial, as voltadas para a área da saúde em países caracterizados por instabilidades políticas e econômicas como o Brasil, o estudo da Fiocruz se prolongava no tempo, continuamente prorrogado e, no início de 2020, apenas resultados parciais haviam sido divulgados para os moradores, ainda restando amostras a analisar cujos resultados os pesquisadores aguardavam. Reconstituo a seguir o desenvolvimento da pesquisa, baseada na minha experiência de campo e no trabalho de Gilmara Silva (2019).

A pesquisa se constituiu como uma parceria entre Fiocruz e Secretaria Municipal de Saúde de Volta Redonda. A Fiocruz se responsabilizou pela análise do material, enquanto a coleta seria responsabilidade da secretaria de saúde, realizada, portanto, pelos técnicos da unidade básica de saúde local do bairro Volta Grande. As análises foram compostas de análises biológicas (de sangue e de urina), análise ambiental (de água, solo e ar), além do preenchimento de 4 longos questionários (de exposição ambiental, avaliação do sono, avaliação clínica e nutricional) e exame clínico (anamnese). Para realizar a coleta das análises, os agentes de saúde iam até às casas das pessoas, mas para o preenchimento dos questionários era necessário o deslocamento do morador até a unidade de saúde.

Em relação à amostragem, para ser representativa, a pesquisa precisaria de no mínimo 400 participantes, cujas casas eram sorteadas. Em novembro de 2018, dois anos após a realização do projeto piloto, 
apenas 228 moradores tinham feito a doação de sangue e urina. Os questionários ainda constavam com número ainda menor de preenchimentos, sendo que era necessário ter um número equivalente de amostras biológicas e questionários para comparação, para que as diversas variáveis pudessem ser correlacionadas.

Muitos outros fatores atravessavam a prática da produção da pesquisa contribuindo para o prolongamento do tempo, como a dependência dos recursos econômicos da SMS, condicionada à temporalidade da tramitação da burocracia municipal, o momento de diminuição do volume de recursos repassados à Fiocruz com a retração econômica e o desinvestimento no financiamento da ciência e pesquisa em função da instabilidade no contexto político nacional, a rotatividade dos agentes de saúde e a necessidade de refazer a formação específica necessária para a execução do trabalho, a interação desses com a população do bairro, que por utilizar plano de saúde privado, não adquiriram o hábito de frequentar as unidades de saúde da localidade.

A junção de todos esses fatores imprimiu uma dinâmica morosa à pesquisa, cujo efeito foi a descrença em parte dos moradores e certo descrédito no processo em vista do atraso e não materialização dos resultados sobre os efeitos na saúde da população. A baixa adesão dos moradores ao estudo era um desafio que já se apresentava desde o início, preocupava bastante os pesquisadores e não foi revertido ao longo do processo. No entanto, essa descrença por parte da população afetada era um reflexo não apenas da temporalidade lenta da pesquisa científica em questão, mas de uma temporalidade que vinha desde um passado mais longínquo, e se estendia a outros cenários e níveis da infraestrutura siderúrgica para os quais as disputas políticas em torno das toxicidades se desdobravam, abarcando um longo processo judicial.

\section{O tardar da justiça: (des)regulação e burocracia ambiental}

Os estudos e a questão da definição sobre os efeitos da contaminação na saúde da população do bairro se inserem num contexto mais amplo que é o quadro burocrático, constituído pela legislação am- 
biental, pelos dispositivos regulatórios das atividades potencialmente poluentes, e o aparato de justiça mobilizado em função das infrações e condutas que divergem dos procedimentos legais. Ambos, a ciência e os estudos e laudos produzidos, assim como o quadro regulatório e o aparato jurídico-legal, são sistemas que compõem a rede da infraestrutura siderúrgica e que envolve a vida dos resíduos tóxicos da CSN e suas consequências para o ambiente e à população.

Infraestruturas são redes em cuja extensão podem ser abrigados sistemas heterogêneos que interagem, dentre eles a burocracia, o sistema jurídico-legal e seu aparato regulatório, formando uma "amálgama de informações técnicas, administrativas e financeiras" (Larkin 2013:330). Para analisar como eles se inserem na infraestrutura siderúrgica e as formas pelas quais a questão da temporalidade envolve a trama burocrática, os dispositivos regulatórios e a mobilização do judiciário (na tentativa de adequação e reparação da situação), retomarei de forma bem sucinta o histórico do caso ${ }^{4}$. A partir disso, examinamos o papel do tempo nas estratégias corporativas como nos processos de contestação social à empresa poluidora.

Em primeiro lugar, é preciso ressaltar que a produção da poluição e o processo de contaminação lenta da cidade ocorrem desde a fundação da siderúrgica na década de 40 , no plano da invisibilidade. Pelo menos desde a década de 1970, a área contígua ao Volta Grande IV já existia como bota-fora da CSN (MPF 2018; Silva 2019). Como consequência, quando o aparato legal e institucional relacionado à questão ambiental foi criado no Brasil, a CSN já operava há quase três décadas.

A criação da secretaria de meio ambiente se dá em 1972 e a instituição da Política Nacional do Meio Ambiente e criação do Sistema Nacional do Meio Ambiente (SISNAMA) datam de 1981. Com o fim da Ditadura Militar em 1985, Volta Redonda deixa de ser Área de Segurança Nacional, e a FEEMA, órgão ambiental responsável na época, passa a atuar na fiscalização, iniciando algum controle ambiental relacionado aos resíduos da CSN. Em 1986, a siderúrgica usa o bairro 
Santo Agostinho como depósito de resíduos, instalado de forma ilegal, sem licença ambiental e sem licença de operação (MPF 2012:4).

Não foi exigido Estudo de Impacto Ambiental/RIMA pra construção desses depósitos de resíduos perigosos, porque a resolução que tornava obrigatória a apresentação do EIA/RIMA como requisito para a concessão da licença foi instituída após a confecção da licença ambiental para a instalação do empreendimento. A emissão da licença de instalação pela FEEMA ocorreu mediante condicionantes de que seria um depósito provisório, de no máximo quatro anos, e que todos os resíduos dispostos no local deveriam ser retirados no prazo de até dezoito meses (MPF 2012:3). Apenas em 1989 sai a primeira licença ambiental do empreendimento. Em 1994, ocorre a privatização da CSN, o que dá início às discussões sobre os passivos ambientais da empresa e a FEEMA firma um Termo de Ajuste de Conduta (TAC) no qual a empresa se comprometia a monitorar as células através da instalação de quatro poços no seu entorno (MPF 2012:5).

Entre 1998 e 2000, as casas do condomínio são construídas e vendidas. Em 2000, a CSN contrata estudos da empresa Hidroplan sobre a área e é constatada a contaminação das águas dos poços de monitoramento. A FEEMA firma outro TAC e é criada a comissão de moradores do VGIV. Em 2004, ocorrem as primeiras denúncias dos moradores ao Ministério Público estadual. Outro estudo, da empresa Nickol, encomendado pela CSN confirma a contaminação das águas subterrâneas e do solo. Em 2005 ocorre um terceiro licenciamento, e, desde então, vários estudos e pareceres técnicos contratados.

Em 2012, é impetrada uma ação civil pública pelo MPF e MPRJ e, em audiência pública, a CSN apresenta estudo que comprova a ampliação da contaminação em outras áreas não consideradas até então. Em 2013, o INEA multa a CSN em 35 milhões de reais pela contaminação. A Procuradoria exige estudos epidemiológicos e informa sobre a pesquisa pela FIOCRUZ em parceria com a SMS. O INEA vira ré no processo e o caso passa para justiça federal por ameaçar o lençol freático do Rio Paraíba do Sul. 
Em 2016 a Fiocruz inicia o piloto da pesquisa. Em 2017, a CSN anuncia os resultados do estudo da NewFields, comprovando que não há contaminação, nem risco à saúde da população. Em 2018, uma nova denúncia pela AHOMAR (Associação Homens e Mulheres do Mar da Baía de Guanabara) gera notificações do INEA à CSN e à Harsco, e levam à realização de Inquéritos Civis Públicos do MPF e MPRJ sobre o depósito de escória. Em 2019, novas multas são determinadas à CSN por descumprimento de liminares em relação às medidas mitigadoras e de remediação para regularização do licenciamento ambiental do pátio de escória operado pela Harsco, cujos resíduos se avolumam, aprofundando a situação de contaminação da área.

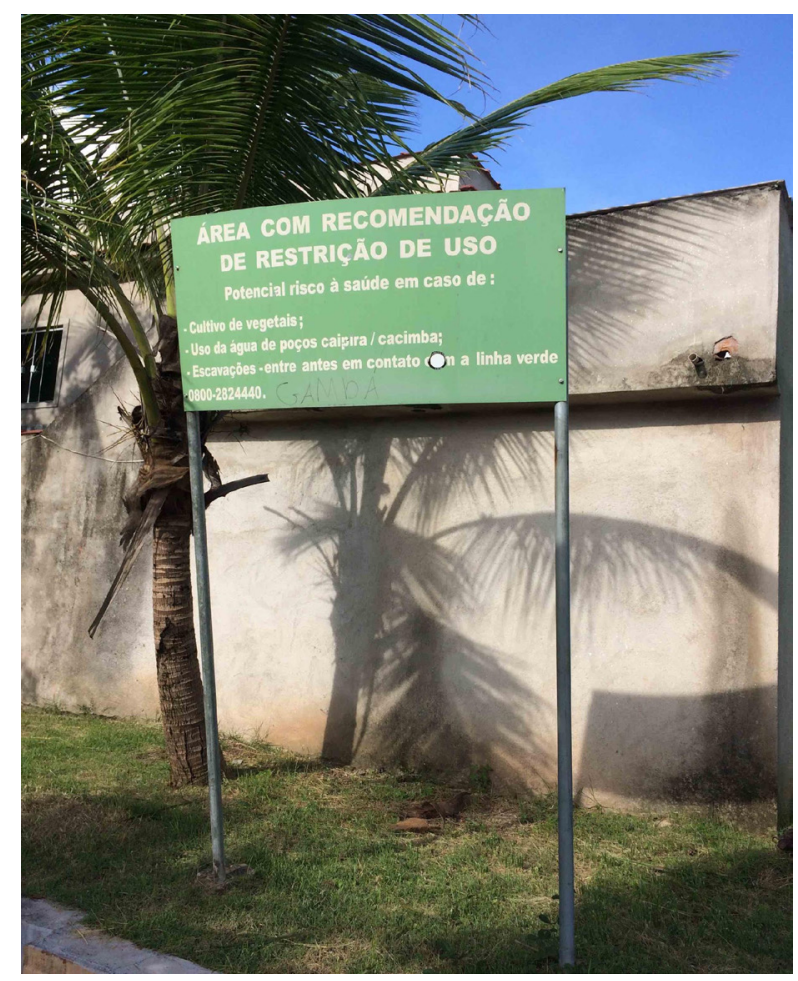

Fotografia 5: Placa na rua do condomínio indicando restrições ao uso do solo por determinação judicial. 


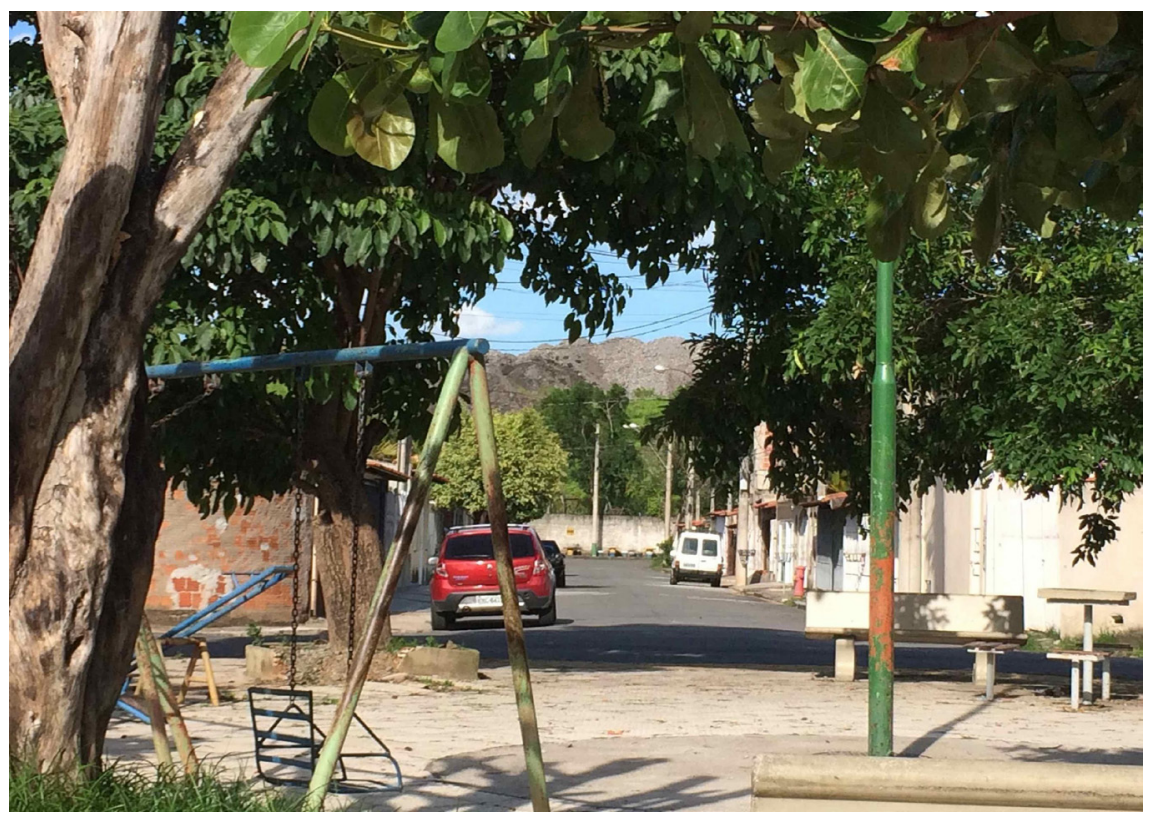

Fotografia 6: Área de lazer dentro do condomínio, ao fundo, a montanha de escória.

Desde que as células para armazenamento de resíduos foram instaladas na década de 1980 de forma ilegal, o depósito recebeu cerca de $6.700 \mathrm{~m}^{3}$ de materiais como borras ácidas, borras de alcatrão, borras oleosas, lama da Estação de Tratamento de Efluentes Químicos da UPV, resíduos da coquerias, solo contaminado, materiais plásticos contaminados com cromo e resíduos laboratoriais, dentre outros não identificados pela ausência de registro de controle das substâncias, lançados na área por parte da CSN.

No solo superficial do condomínio VGIV, foram encontrados compostos carcinogênicos e tóxicos em concentrações acima das aceitáveis pelo CETESB (Companhia de Tecnologia de Saneamento Ambiental) e pelo Ministério da Saúde, como hexaclorobenzeno, PCBs, dioxinas e furanos. Assim como a presença de resíduos de cor escura 
e roxa e alta concentração de contaminantes em áreas de lazer e nas residências. Um estudo epidemiológico realizado no condomínio em 2004, indicou uma considerável incidência de abortos e leucopenia na população residente (MPF 2012:6).

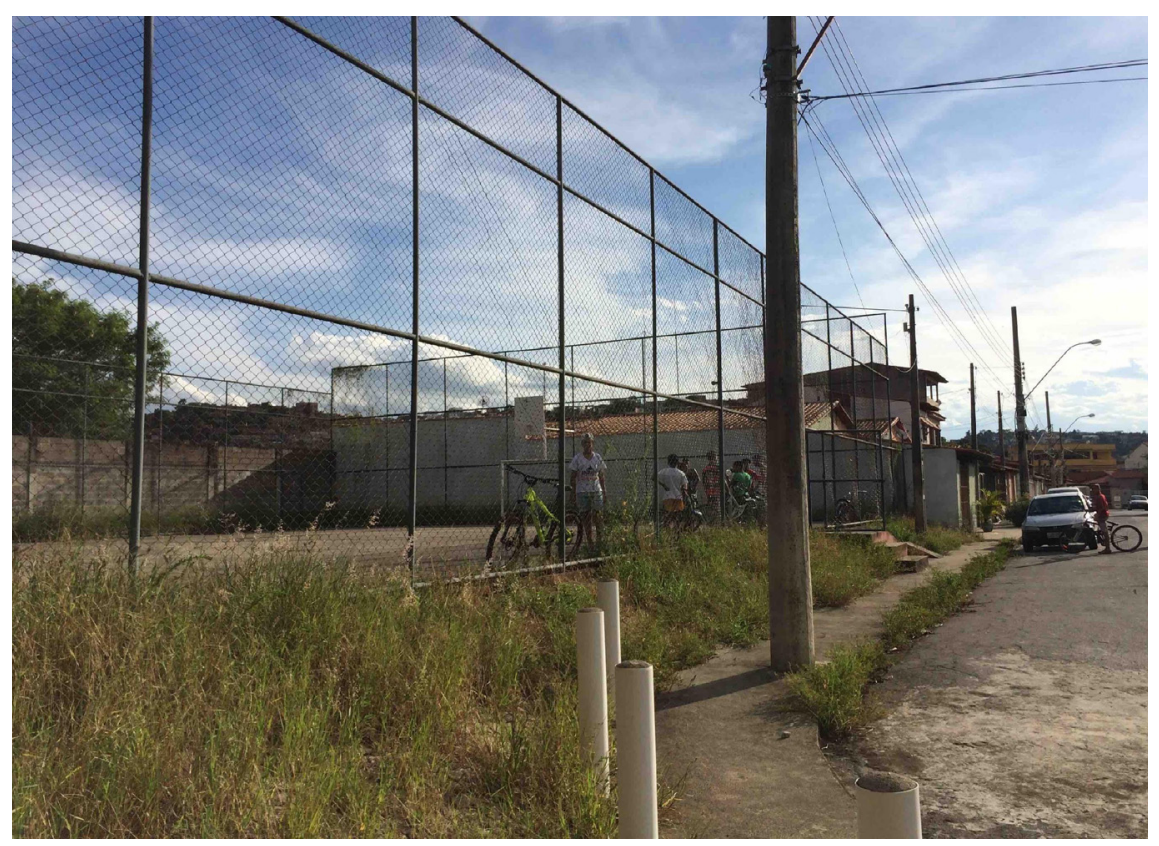

Fotografia 7: Área interna do condomínio onde ocorreu o vazamento e a desapropriação de casas, transformada em área esportiva.

O pátio de beneficiamento da Harsco, usado há décadas pela CSN para despejo de seus resíduos industriais diretamente no solo, é situado na área de preservação permanente do rio Paraíba do Sul, ao lado de uma unidade de conservação de proteção integral. O local recebe por mês cerca de 80.000 toneladas de resíduos, totalizando cinco milhões de toneladas de escória da CSN (MPF 2018:4,6). A venda do material beneficiado alcança um volume bem abaixo, em torno de 30.000 toneladas, portanto, a quantidade de resíduos siderúrgicos 


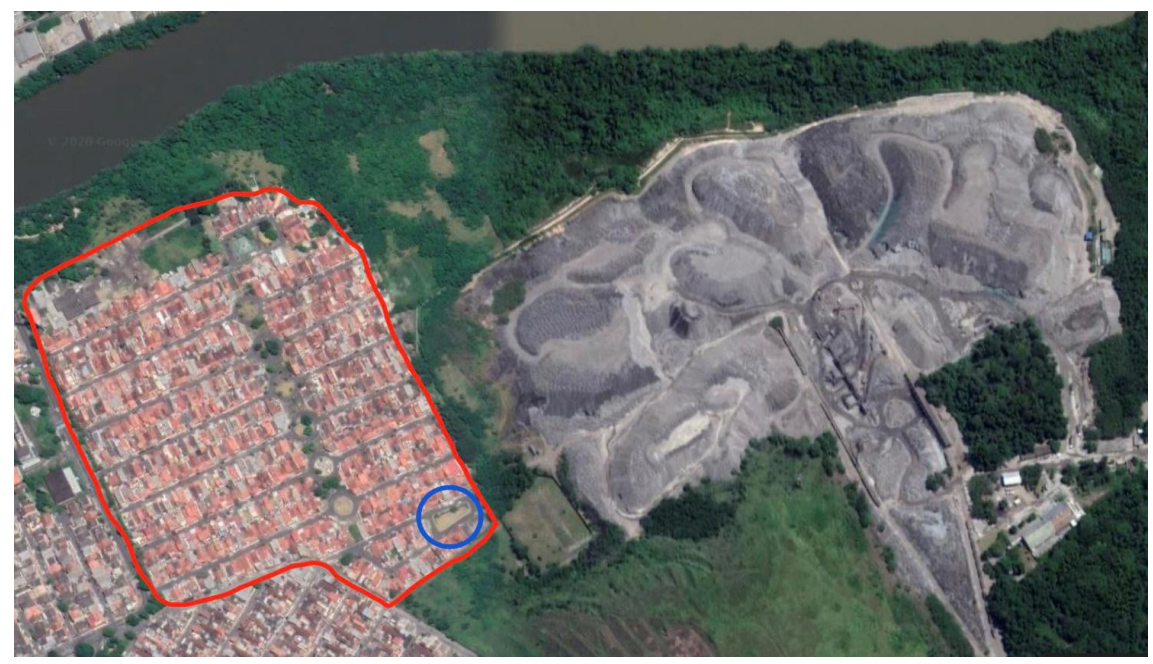

Fotografia 8: Imagem de satélite destacando a área do condomínio, o local do vazamento dos poços transformada em área de lazer, a montanha de escória na área de proteção ambiental e as margens do Rio Paraíba do Sul.

Desse modo, a atividade intensiva da CSN no centro da infraestrutura siderúrgica teve como resultado a fabricação de 'paisagens tóxicas' (Stewart 2017). O acúmulo de milhares de toneladas de resíduos na área limítrofe ao condomínio resultou na formação de gigantescas montanhas de escória, cuja contaminação se difunde a partir de vários agenciamentos no ambiente, alcançando não apenas o solo, mas o ar, as águas subterrâneas, os organismos, com efeitos diversos ao longo do tempo.

É importante ressaltar que, em todo esse processo, há um vício de origem. $\mathrm{O}$ fato de a empresa começar a operar antes da existência do aparato legal e regulatório, tendo atuado sem controle ambiental, gerando contaminantes na invisibilidade. Esse vício de origem dá margem a inúmeras tentativas de ajustes e reparações posteriores, que nunca se completam e que se estendem indefinidamente no tempo e na justiça, sem, no entanto, surtir efeito para mudanças concretas no 
modo de atuação da empresa, com remediação dos danos, compensação para os afetados, prevenção de novas, e reversão das já existentes, contaminações.

No contexto brasileiro, estudos antropológicos sobre os dispositivos do aparato regulatório e da burocracia ambiental, como os de Andrea Zhouri et al (2017) e Debora Bronz (2016), ressaltam seu objetivo, ou ao menos seu efeito prático, de viabilizar a construção ou o funcionamento de grandes empreendimentos industriais. Em relação ao caso Volta Grande IV, Silva (2019:124) também sublinhou o papel do estado e suas instituições na promoção dos empreendimentos, das injustiças ambientais e da vulnerabilização das populações.

Se como sugeriu Goldstein "é a natureza não vista da toxicidade que permite ao Estado autorizar sua existência” (2017:321), seguindo Hecht entendemos que quando um resíduo se torna visível, junto com ele vem 'novas demandas pela sua governança' (2018). Ela define 'governança residual' como aquela que aborda o problema de modo restrito, isolando um pequeno pedaço do problema e ignorando suas implicações mais amplas, pensada a posteriori, como uma reflexão tardia, terminando por tratar as pessoas como resíduos.

De fato, pesquisas etnográficas em contextos de contaminação e violência lenta (Nixon 2011) apontam os sistemas regulatórios e compensatórios como mecanismos que operam não para coibir ações e salvaguardar as populações, mas para permitir as práticas corporativas que produzem poluição. "O Estado e seus sistemas relacionados fazem parte da estrutura de toxicidade que permite que a ubiqüidade e a tonelagem de tóxicos sejam produzidas e circulem em primeiro lugar" Liboiron et al 2018:336), e ao estabelecerem valores-limite legais para o dano tóxico, intoxicantes terminam sendo "sistemática e legalmente permitidos na água, nos ambientes e organismos através de estruturas reguladoras" (Liboiron et al 2018:335) expondo corpos e ecossistemas e oferecendo riscos e danos a territórios e populações (Murphy 2013; Hecht 2018; Liboiron et al 2018; Boudia \& Jas 2014). 


\section{O tempo na arena ambiental: estratégias corporativas e contestação social}

A disputa em torno da contaminação e sua toxicidade transforma a infraestrutura siderúrgica numa arena política, na qual a questão ambiental ganha relevância, dispondo no espaço grupos heterogêneos que se confrontam e lançam mão de táticas e repertórios de ação distintos, de modo a alcançarem seus interesses diante dos desiguais recursos e graus de influência e poder que possuem.

Nos quatro cenários analisados, a contaminação, a controvérsia científica, o processo judicial e a arena ambiental, o tempo se mostrou um elemento central, atravessando diferencialmente a infraestrutura, sendo utilizado e apropriado pelos atores, e configurando, a partir de agenciamentos específicos, situações e relações com distintos efeitos políticos.

A temporalidade lenta da contaminação na formação da 'paisagem tóxica' da cidade, que nasce com e em função da CSN, dificulta a percepção da poluição pela população, dada sua condição generalizada na cidade. Davies aponta a lentidão do acúmulo de intoxicantes como o fator que permite que sejam "onipresentes ainda não reconhecidos, resultando acúmulo dos danos ao longo do tempo e dificultando também epidemiologicamente e geograficamente a localizar os responsáveis" (2018:1538).

Ayuero \& Swistun falam em "dispersão temporal da contaminação" (2008:360) para caracterizar esse processo de normalização da poluição, que produz percepções equivocadas a respeito da toxicidade e seus riscos. Eles analisam o caso de uma comunidade aonde apesar de décadas de encubação lenta da poluição no ambiente, nenhum evento foi capaz de quebrar a rotina cotidiana levando à mobilização diante dos riscos da exposição aos tóxicos, não havendo conhecimento compartilhado nem entendimento comum sobre a toxicidade.

O caso do Volta Grande IV parece se inserir em uma configuração específica, misturando dois paradigmas. Se de um lado há um evento que quebra a percepção sobre o andamento rotineiro da vida, 
quando, em 2003, apareceram rachaduras e líquidos com cheiro forte no chão das casas do condomínio despertando preocupação nos moradores (MPF 2012). Do outro, a população de Volta Redonda vive em um contexto de longa exposição a poluição e intoxicantes, em função da história da cidade que emerge com a CSN. Por essa razão, especialistas e ativistas locais enxergam um processo de "naturalização da poluição" (Silva 2019:121; Brígida 2015), que assume sentidos políticos ao operar certa blindagem cognitiva que não mobiliza para a luta, favorecendo a continuidade da exposição aos contaminantes e legitimando seu aumento progressivo.

Nesse sentido, não há homogeneidade nas percepções dos moradores sobre a contaminação no condomínio, e é preciso assinalar as bases, relações, pertencimentos, sentimentos e lógicas que fundamentam essa clivagem, como elas influenciam as percepções sobre a toxicidade e suas implicações políticas. Uma parte dos moradores é composta por funcionários da CSN, o que restringe o engajamento político e a reflexão crítica sobre a exposição tóxica por medo de retaliação da empresa e consequente perda do emprego. Outra parte dos moradores permanece imersa na continuidade rotineira da vida e suas questões práticas, mantendo o interesse no caso menos pelos possíveis danos à saúde que a toxicidade oferece do que pelos impactos (do reconhecimento) desta na (des)valorização de seus imóveis, como expõem em suas falas nas reuniões públicas.

Outros, mais mobilizados, fazem parte da comissão de moradores e levam adiante o trabalho político de cobrar da empresa ações para a segurança da saúde de suas famílias e do ambiente em que vivem, participando de reuniões, audiências, que caracterizam uma prática ativista. É remontando à história de vida que podemos compreender os fundamentos e sentidos desse engajamento político. $\mathrm{O}$ exemplo biográfico de um dos membros da comissão é elucidativo:

O meu pai veio para Volta Redonda por causa da CSN, para trabalhar. Ele queria os filhos estudando na escola técnica, automaticamente, trabalhando na CSN. Meu irmão mais velho entrou, meu 
irmão do meio e eu também. [...] Meu envolvimento com a Pastoral da Juventude era muito forte. Então, comecei a me rebelar em relação à empresa, pela postura dela com os funcionários. Porque eu entrei na CSN no período pós privatização. [...] Sempre fui ligado aos movimentos eclesiais de base, à Pastoral da Juventude. E ela acaba estimulando o que? A nossa militância. (Entrevista concedida em 18/01/2017).

O depoimento remonta ao tecido associativo que caracterizou a cidade especialmente após a privatização da CSN e aponta para a importância de ampliar a escala de análise, incorporando as temporalidades ligadas à formação histórica e política de Volta Redonda para compreender as condições de possibilidade dos processos de contestação social à empresa no caso estudado.

Os territórios englobados pelas redes globais de produção mínero-siderúrgicas da CSN, como Congonhas (MG) e Volta Redonda (RJ), vêm apresentando potencial inovador no que tange à criação de formas de contestação social e confronto político, especialmente, fazendo convergir pautas e atores sociais tradicionalmente cindidos, como as questões trabalhista e ambiental (Ramalho et al 2013:189). É no mapeamento dessa dinâmica política que a presente análise se insere a partir do caso do Volta Grande IV.

Como vimos, a complexidade dos processos de determinação da toxicidade e seus efeitos, e as condições sociais e políticas locais e nacionais para realização de pesquisas que a envolvem, fazem da produção da ciência uma atividade vagarosa, continuamente prorrogada, que se estende no tempo. Incorporada aos processos judiciais, os estudos para identificação dos danos ambientais e de saúde se inserem na arena jurídica, que possui, do mesmo modo, uma temporalidade própria.

Estudos como da NewFields, divulgados à comunidade de modo espetacular, em semelhança a peças de marketing, para além da dimensão política da performatividade, ganham sentido quando inseridos no marco do envolvimento da empresa na disputa judicial, que 
pelo princípio do poluidor-pagador foi instada ao encargo de provar que sua atividade não enseja riscos potenciais ou danos para o meio ambiente, com o estabelecimento da inversão do ônus de prova (MPF 2018:43). O modo de mobilizar a justiça e protelar sua resolução por parte da CSN se mostra um dispositivo de produção de tempo, prolongando o não cumprimento e adiando a adequação das operações e medidas efetivas de reparação e remediação da situação de contaminação.

Nesse sentido, a não efetividade das legislações, regulamentações, sanções e outros mecanismos da burocracia ambiental em impedir a continuidade dos danos ao ambiente e à saúde, e realizar sua reparação, permite pensar como o aparato jurídico-legal é apropriado pela empresa enquanto estratégia corporativa, transformando-se em recurso para continuar seus empreendimentos e evitar custos com compensações e reparações eficazes e justas.

Por outro lado, a questão ambiental, transformada em pauta política, e a existência do aparato jurídico-legal relativo ao meio ambiente levaram a um processo de contestação social à empresa na cidade. $\mathrm{O}$ evento do vazamento nos poços de monitoramento desencadeou um processo de visibilização dos efeitos da atividade da empresa, que até então tinha atuado na invisibilidade, inscrevendo-os no debate público, com a formação de uma coalizão crítica à siderurgia na cidade.

As estratégias dos atores da coalizão crítica à atividade siderúrgica repousam na capacidade de trazer à tona os perigos e riscos da produção industrial, colocando-os assim no campo do visível, inscrevendo-os na disputa política. Desse modo, os resíduos tóxicos deixam de ser matérias inertes e passam a ser agenciados politicamente, transformando-se em mediadores na arena ambiental da infraestrutura siderúrgica.

Se, de um lado, o aparato jurídico-legal da burocracia ambiental é manipulado e transforma-se em recurso que produz tempo, prolongando e estendendo processos que protelam soluções efetivas para as populações e territórios, aprofundando as vulnerabilidades e violências destas ao favorecer a ação e captura de valor dos agentes econômicos, de outro, a legislação ambiental e seus dispositivos regulatórios 
também são apropriados pelos atores sociais, tornando-se recursos capazes de produzir redes sociopolíticas e mobilizar agentes na formação de coalizões críticas à empresa.

O caso que começa com a descoberta da contaminação do solo das casas por conta do vazamento nos poços, com o tempo, vai operando o deslocamento da atenção e da atuação dos moradores atingidos, dos ambientalistas e dos agentes da justiça para a montanha de escória a céu aberto que constitui o depósito de resíduos da aciaria. Ao entrar no foco de atenção, discursivo e de ação, a montanha de escória vai operando uma materialização do emaranhado de relações entre humanos e não-humanos na infraestrutura siderúrgica, ampliando a 'percepção do ambiente' (Ingold 2000) dos sujeitos envolvidos para os múltiplos agenciamentos da toxicidade da escória no ar, na água, no solo e nos corpos humanos.

Além da contaminação do solo, e, sobretudo, com a montanha de escória, a preocupação com os efeitos da atividade siderúrgica passa a incluir a poluição visual, atmosférica, hídrica, em vista da operação sem controle de emissões atmosféricas, da lixiviação com contaminação do lençol freático, e do risco de desabamento sobre o rio Paraíba do Sul, anunciado na mídia como uma tragédia iminente tal qual a de Mariana $(\mathrm{MG})^{5}$. As partículas tóxicas da escória se dispersam no ar e moradores relatam aumento de poeira em suas casas (Silva 2019:119), cuja inalação gera doenças respiratórias. $\mathrm{O}$ engajamento de diversos atores em torno da questão ambiental forma uma coalizão que envolve comissão de moradores, Comissão Ambiental Sul, Fiocruz, Ministério Público, Ongs, numa rede com potencial de ampliação. O resultado desse processo de mobilização resultou na criação, em 2018, do Movimento dos Atingidos pelo Pó da CSN, impulsionando e fortalecendo a contestação.

\section{Uma política resiliente: à guisa de conclusão}

Neste artigo, desenvolvemos conceitualmente a noção de 'infraestrutura siderúrgica' como um prisma de análise capaz de integrar e 
pôr no foco da discussão as dimensões invisíveis ou opacas que constituem a atividade produtiva da siderurgia em Volta Redonda, a partir do caso da contaminação do condomínio Volta Grande IV, área na qual a empresa por mais de quatro décadas despejou seus resíduos tóxicos. Se o município por conta da siderúrgica ficou conhecido como 'Cidade do aço', o artigo apostou na análise dos tóxicos e seus agenciamentos como forma de explorar as dinâmicas e efeitos políticos que engendram, de modo a revelar, com o lado residual da infraestrutura siderúrgica, a 'Toxicidade do aço'.

A toxicidade, como salientou Liboiron e outros, diz respeito ao modo como formas de vida, e as relações que as constituem, são permitidas, restringidas ou extintas dentro de sistemas de poder mais amplos. Desse modo, ela é parte desses sistemas, mas, no entanto, possui também o potencial de inventar relações políticas alternativas. "A precariedade de mundos tóxicos permite a formação de resistências, coalizões e práticas que expandem o inventário do que a política significa e faz no industrialismo tardio" (2018:341).

A análise etnográfica da política da toxicidade se desdobrou em quatro cenários da infraestrutura siderúrgica, e o tempo foi a variável que permitiu compreender os agenciamentos e estratégias dos atores na conformação das dinâmicas políticas em torno dos tóxicos, na medida em que temporalidades atravessavam diversos níveis e dimensões da infraestrutura produzindo efeitos diferencialmente. Nesse sentido, o tempo permitiu compreender as relações de poder, mapear injustiças, revelar constrangimentos e violências, assim como identificar resistências e potencialidades.

Pesquisas antropológicas recentes têm dado atenção ao tempo como objeto etnográfico, enfocando especialmente as temporalidades do viver e suas dimensões políticas (Martínez 2019). Ozolina (2019) descreve a 'espera' como forma de governamentalidade neoliberal, fornecendo uma contribuição importante para discussões contemporâneas sobre a temporalidade do que é politicamente invisível, já Bandak \& Janeja (2018) apontam a espera como ferramenta política, 
capaz de demonstrar poder, produzir estruturas particulares de sentimento e moldar formas de resistência e micropolítica.

Nos cenários da infraestrutura siderúrgica analisados, o tempo assume um papel ambíguo, atuando distintamente sobre os atores. Se por um lado, a temporalidade lenta da contaminação, da ciência e da justiça é agenciada e apropriada enquanto um recurso para a siderúrgica, compondo suas estratégias corporativas e produzindo cansaço nos afetados, forçando sua desistência ou desesperança, por outro, os processos de contestação e as estratégias de mobilização dos atores, mediante a espera, impelem à constituição de uma política da resiliência.

Como comentou um dos membros da comissão de moradores: "Porque a CSN, eu acho que ela esperava que o nosso cansaço acontecesse antes. Eu acho que ela nem sabe que nós estamos cansados" (Entrevista concedida em 18/01/17). Fundada em 2004, a comissão voluntária de moradores do condomínio, que chegou a ter uma sede contando cerca de 350 membros, hoje possui poucos representantes, restando apenas os mais obstinados, para os quais a política vem acompanhada de um sentido ético, que fundamenta e não se dissocia de um senso de justiça.

As disputas e relações de poder na infraestrutura siderúrgica se inscrevem não apenas num âmbito formal, mas no plano cotidiano, das vivências, nas quais as percepções, os afetos e ações dos atores são definidores das estratégias e potencialidades postas num jogo de forças injusto e desigual, mas do qual desistir não se apresenta como possibilidade, uma vez que sua continuidade se confunde com as existências materiais dos sujeitos e dos sentidos morais, éticos, que o engajamento persistente confere a elas.

Nesse sentido, uma política resiliente à toxicidade se aproxima da ideia de um "ativismo lento" (Liboiron et al 2018:341), aquele cujos efeitos das ações demoram para aparecer, não necessariamente envolvem uma mudança do sistema, nem se definem pela eficiência, mas pela ética. Diante da persistência da contaminação, da incerteza, da 
injustiça e da violência, seguir existindo, firmes, à espera de mudança, é uma ação política. Como me disse uma integrante do núcleo duro da comissão de moradores do bairro: "Hoje, a gente é conhecido assim “um grupo resistente”" (Entrevista concedida em 25/01/17).

\section{Notas:}

1 Essa pesquisa foi financiada com uma bolsa de Pós-Doutorado pelo Programa de Apoio à Pós-Graduação e à Pesquisa Científica e Tecnológica em Desenvolvimento Socioeconômico através do Edital n 42/2014 da Coordenação de Aperfeiçoamento de Pessoal de Nível Superior (CAPES).

2 A descrição do caso dessa seção é baseada no trabalho de Irinéa Brígida (2015), umas das principais referências sobre o caso, e na Ação Civil Pública do MP (2012).

3 A Fundação Oswaldo Cruz (Fiocruz) é uma instituição de pesquisa e desenvolvimento em ciências biológicas considerado um dos principais centros de pesquisa em saúde pública no país e mundialmente.

4 O histórico é baseado em dois trabalhos de referência sobre o caso - Brígida 2015 e Silva 2019, e nas peças das ações e inquéritos do Ministérios Públicos nas instâncias federal e estadual (MPF 2012, 2018).

5 https://odia.ig.com.br/rio-de-janeiro/2018/06/5549776-rio-paraiba-do-sul-esta -ameacado-de-sofrer-desastre-ambiental.html?fbclid=IwAR2n4nqrQEB4HpOYNsRCs16IBZRb2intsA--H4bIHPg1Eox0XmHUZt4wMEA\#foto=1.

\section{Referências:}

ANAND, N., GUPTA, A. \& APPEL, H. (eds.). 2018. The promise of infrastructure. Durham: Duke University Press.

AUYERO, J. \& SWISTUN, D. 2008. "The Social Production of Toxic Uncertainty". American Sociological Review, 73(3):357-379.

BECK, U. 2010. Sociedade de Risco: rumo a uma outra modernidade. São Paulo: Ed. 34.

BOUDIA, S. \& JAS, N. (eds). 2014. Powerless Science?: Science and Politics in a Toxic World. New York: Berghahn Books.

BOWKER, G. 1994. Science on the run: Information management and industrial geophysics at Schlumberger. Cambridge, MA: MIT Press.

BRÍGIDA, I. 2015. Conflitos socioambientais em Volta Redonda: o caso Volta Grande IV. Dissertação de Mestrado. Niterói: Universidade Federal Fluminense. 
BRONZ, D. 2016. Nos Bastidores do Licenciamento Ambiental. Uma etnografia das práticas empresariais em grandes empreendimentos. Rio de Janeiro: Contra Capa.

COSTA, C. M. L., PANDOLFI, D. \& SERBIN, K. (eds.). 2001. O bispo de Volta Redonda: memórias de Dom Waldyr Calheiros. Rio de Janeiro: Ed. FGV.

DAVIES, T. 2018. "Toxic Space and Time: Slow Violence, Necropolitics, and

Petrochemical Pollution”. Annals of the American Association of Geographers, 108(6): 1537-1553.

DE ANGELIS, M. 2014. "Marx and primitive accumulation: The continuous character of capital's 'enclosures'". The Commoner, 2:1-22.

DICKEN, P. 2001. Destroying value: environmental impacts of global production networks. Global Shift. New York: the Guilford Press.

GILLE, Z. 2010. "Actor networks, modes of production, and waste regimes: reassembling the macro-social". Environment and Planning A, 42(5):1049-1064.

GOLDSTEIN, D. M. 2017. "Invisible harm: science, subjectivity and the things we cannot see". Culture, Theory and Critique, 58(4):321-329.

GRAHAM, S. \& MCFARLANE, C. 2015. (eds.). Infrastructural lives: urban infrastructure in context. London/ New York: Routledge/ Taylor \& Francis Group.

HECHT, G. 2018. Residue. (http://somatosphere.net/2018/residue.html/; acesso 20/03/2020).

HEROD, A. et al. 2014. "Global destruction networks, labour and waste". Journal of Economic Geography, 14(2):421-441.

HETHERINGTON, K. (ed.). 2019. Infrastructure, environment, and life in the Anthropocene. Durham: Duke University Press.

INGOLD, T. 2000. The Perception of the Environment. Essays in Livelihood, Dwelling and Skill. London/New York: Routledge.

JANEJA, M. K.; BANDAK, A. 2018. (eds.). Ethnographies of waiting: doubt, hope and uncertainty. London, UK; New York, NY, USA: Bloomsbury Academic, an imprint of Bloomsbury Publishing, Plc.

LARKIN, B. 2013. "The Politics and Poetics of Infrastructure". Annual Review of Anthropology, 42:327-343.

LERNER, S. 2010. Sacrifice zones: the frontlines of toxic chemical exposure in the United States. Cambridge/Massachusetts: The MIT Press.

LIBOIRON, M., TIRONI, M. \& CALVILLO, N. 2018. "Toxic politics: Acting in a permanently polluted world". Social Studies of Science, 48(3):331-349.

LIMA, R. J. 2010. A Reinvenção de cidade industrial: Volta Redonda e o pós privatização da Companhia Siderúrgica Nacional. Tese de Doutorado. Rio Janeiro: UFRJ.

. 2013. "CSN e Volta Redonda: uma relação histórica de dependência e controle". Política \& Sociedade. 12(25):41-64.

2012. "Articulação e reorganização sociopolítica em Volta Redonda no pós-privatização da CSN". In RAMALHO, J. R. \& FORTES, A. (eds.). Desenvolvimento, trabalho e cidadania: Baixada e Sul fluminense, pp. 203-224. Rio de Janeiro: 7 Letras. 
MARTINEZ, F. 2019. "Waiting Cultures, Temporal Marginality, and the Politics of Stillness". Anthropological Journal of European Cultures, 28(2):108-127.

MCGRATH-CHAMP, S. et al. 2015. "Global destruction networks, the labour process and employment relations". Journal of Industrial Relations, 57(4):624640.

MILANEZ, B. \& PORTO, M. 2008. "A ferro e fogo: impactos da siderurgia para o ambiente e a sociedade após a reestruturação dos anos 1990”. In Encontro Nacional da Annpas, 4. Anais eletrônicos. Brasília: Distrito Federal. (www.anppas. org.br/encontro4/cd/gt6.html>; acesso em 15/02/2020).

MINISTÉRIO PÚBLICO FEDERAL; PROCURADORIA DA REPÚBLICA NO MUNICÍPIO DE VOLTA REDONDA. 2012. Ação Civil Pública. Volta Redonda. . 2018. Inquéritos Civis Públicos n. 08120.001452/97-04 e 1.30.010.000159/2000-29. Volta Redonda.

MURPHY, M. 2013. "Chemical Infrastructures of the St Clair River". In JAS, N. \& BOUDIA, S. (eds.): Toxicants, Health and Regulation since 1945, pp. 103 116. New York: Pickering \& Chatto.

NIXON, R. 2013. Slow violence and the environmentalism of the poor. Cambridge, Mass.: Harvard Univ. Press.

OFRIAS, L. 2017. "Invisible harms, invisible profits: a theory of the incentive to contaminate". Culture, Theory and Critique, 58(4):435-456.

OZOLINA, L. 2019. Politics of Waiting: Workfare, Post-Soviet Austerity and the Ethics of Freedom. Manchester: Manchester University Press.

PIQUET, R. 2012. "O papel da cidade-empresa na formação urbana brasileira". Anais: Seminário de História da Cidade e do Urbanismo, 4(3):688-695.

RAMALHO, J. R. \& FORTES, A. 2012. Desenvolvimento, trabalho e cidadania: Baixada e Sul Fluminense. Rio de Janeiro: 7 Letras.

RAMALHO, J. R., SANTOS, R. \& LIMA, R. 2013. "Estratégias de desenvolvimento industrial e dinâmicas territoriais de contestação social e confronto político”. Sociologia e Antropologia. 3(5):175-200.

RAMALHO, J. R. 2012. "Fórum Demissão Zero: crise ação coletiva no Sul Fluminense”. In RAMALHO, J. R. \& FORTES, A. (eds.). Desenvolvimento, trabalho e cidadania: Baixada e Sul fluminense, pp. 225-246. Rio de Janeiro: 7 Letras.

SANTOS, R. 2015. "Da estratégia corporativa à ação economicamente relevante: a CSN e a contestação social na mineração de ferro". Revista Pós Ciências Sociais, 12(24):143-166.

SILVA, G. 2019. As relações entre a saúde e a exposição aos resíduos siderúrgicos: o conflito socioambiental no Volta Grande IV a partir dos seus moradores. Dissertação de Mestrado. Rio de Janeiro: FIOCRUZ/ENSP.

STAR, S. L. 1999. "The Ethnography of Infrastructure". American Behavioral Scientist, 43(3):377-391. 
STEWART, H. 2017. "Toxic landscape: Excavating a polluted world". Archaeological Review from Cambridge, 32(2):25-37.

VEIGA, S. M. \& FONSECA, I. 1990. Volta Redonda, entre o aço e as armas. Petrópolis: Vozes.

VENKATESAN, S. et al. 2018. "Attention to infrastructure offers a welcome reconfiguration of anthropological approaches to the political". Critique of Anthropology, 38(1):3-52.

ZHOURI, A. et al. (2018). "O desastre do Rio Doce: entre as políticas de reparação e a gestão das afetações". In ZHOURI, A. et al (eds.): Mineração: violências e resistências: um campo aberto à produção de conhecimento no Brasil, pp. 28-64. Marabá: Editorial iGuana/ ABA.

\begin{abstract}
The article analyzes the case of contamination of the "Volta Grande IV' neighborhood by industrial waste from Companhia Siderúrgica Nacional (CSN), in the city of Volta Redonda, South of Rio de Janeiro State, Brazil. The notion of 'steelmaking infrastructure' is developed as a key concept that enables to integrate conceptually and ethnographically the invisible dimension of steel production, by focusing on the residual side of the infrastructure, characterized by toxicity. The focus is to understand power relations and political dynamics engendered by toxic substances in the configuration of contentious arenas around their potential uses and effects. The ethnographic narrative proceeds by presenting four scenarios - contamination, scientific controversy, the legal process and the environmental arena - and adopts time as a privileged object, discussing the ways in which divergent temporalities differentially traverse infrastructure and its political effects in the construction of corporate strategies and social contestation processes, that shape a 'resilient politics'.
\end{abstract}

Keywords: Environmental justice, Toxic waste, Steel industry, Infrastructure, Time.

Recebido em setembro de 2020. Aprovado em dezembro de 2020. 